\title{
Nusa Penida in The Past and Present: A Study of The Pattern of Socio-Cultural Life From Agriculture to Tourism
}

\author{
Ni Made Suwendri ${ }^{1 *}$, I Made Mardika ${ }^{2}$ and Ida Bagus Astika Pidada ${ }^{3}$ \\ Universitas Warmadewa, Denpasar-Bali, Indonesia \\ \{suwendri63@gmail.com¹,dikamar73@gmail.com², astikapidada@gmail.com³
}

\begin{abstract}
Nusa Penida refers to a small island located across the mainland of Bali Island. Geographical condition of the island is made of a hilly limestone area which is often considered as an isolated area with a stagnant pattern of its inhabiting community life. In reality, however, Nusa Penida features a dynamically developing phenomenon of change. In respect of this condition, this study aims to reveal the pattern of the people's sociocultural life of Nusa Penida during traditional agriculture to tourism industry. The problem in this study were examined using three theories: Theory of Cultural Ecology, Structural-Functional Theory and Theory of Sociology of Tourism. The study was conducted using a qualitative research method with a historical approach. The research data were collected through an in-depth interview and literature study. Data were analysed using a qualitative descriptive method. The results showed that the pattern of the people's socio-cultural life of Nusa Penida from agriculture to tourism, respectively, had its own characteristics, that is to say, traditional-agrarian, commercial-oriented traditional life patterns, and the tourism period led to the prominence of tourism services.
\end{abstract}

Keywords: community pattern of life; traditional agriculture; tourism

\section{Introduction}

As part of the District of Klungkung area, Nusa Penida which is located across the island of Bali, has attracted the attention of researchers. Several studies having been conducted concentrated more on the anthropological dimension of culture and tourism. Studies on the utilization of the Nusa Penida coastal area in the seaweed sector were conducted by Sudana Astika (1998), Buda (2005), and Suwendri $(2005,2018)$. Studies on tourism sector focusing on mapping the potential of tourism objects and management strategies were conducted by Damayanti, et al. (2015), Budi Shantika, et al. (2018), and Ariasa, et al. (2018). Unfortunately, of the studies conducted there is not a single study that has precisely highlighted the patterns of changes in the life of the community of Nusa Penida which are essentially developing dynamically. In fact, from a historical perspective, trends in the socio-cultural life of the people of the island designate a development that is undeniably interesting to be analysed through scientific studies.

A head of the development of seaweed cultivation, most of the people of Nusa Penida had been farming by cultivating unirrigated fields as their main livelihood sources; meanwhile, livestock and fisheries were only a leisure pursuit. At that point, the community was still classified merely as a resident with traditional village agriculture (Giddens, 1991). 
Agricultural production was solely to meet household needs because there was no market orientation.

In the 1990s, the time when seaweed began to be widely cultivated by local residents, the coastal area became densely populated with seaweed cultivation. Cultivation of the plant turned into a business for the community and grew rapidly in Nusa Penida until 2013. At the same time, the scope of community life began to lead to advanced agricultural villages (Kistanto, 2018: 172). Subsequently, the agricultural system became commercially oriented.

In 2015, a new trend emerged in Nusa Penida. The island developed into a tourist destination. The presence of this sector, in turn, shifted the seaweed farming. Tourism activities began to spread to villages around the tourist object. Various tourism support facilities were established. Ultimately, the island grew to serve as one of the main tourist attractions in Bali.

Taking into account the stages of the development of the life of the people of Nusa Penida during these three periods, it appears that a distinctive pattern in each period has been formed. Scientifically, this phenomenon has properties that are really interesting to be explored. Established on the fact, the question brought up with the present study is "What were the characteristics of the socio-cultural life patterns of the community of Nusa Penida during the agricultural period until the tourism industry period?"

\section{Review of Literature}

In an effort to reveal the patterns of the life of the people of the village of Nusa Penida starting from the traditional agricultural era to the era of the tourism service industry, an analysis was carried out by making use of relevant concepts and theories, which include Theory of Cultural Ecology and Structural-Functional Theory. In their application, these theories were implemented out in an eclectical manner with the purpose that a deeper understanding would be obtained. The Theory of Cultural Ecology was used to reveal how the people of Nusa Penida village take advantage of the natural environment and how they adapt to their culture. This approach was first applied by Steward and then by Poerwanto in her analysis of the life of the people who lived around the slopes of Merapi, Central Java (2000: 68-71). Steward revealed that cultural ecology appears as a field of study that studies how humans as living things adapt to certain geographic environments. There is an interrelation between culture and its environment. Steward's analysis emphasizes on the relationship between behaviour patterns in a community and the technology used, so that citizens of a culture are able to carry out their activities and ultimately be able to survive. Thus, there is an interplay between the natural environment and human culture. Culture is influenced by the environment and the environment can be changed by that culture. The analogy according to the standpoint represents that adherents of environmental determinism view that environmental conditions play a major role in shaping culture. On the other hand, adherents of possibelism assume that basically geographical factors cannot fully form a human culture. The effect is only up to a certain level of culture.

Kaplan and Manners (1999: 101-107) articulated that there are two central concepts in cultural ecology, that is to say, environment and adaptation. The environment in the perspective of cultural ecology can be interpreted as the reciprocal influence of the natural environment that has been changed by human culture on human life and behaviour at a certain location on earth. It can be said that culture transforms in the process of human adaptation in 
interacting with their environment. Likewise, on the contrary, the existence of an environment has the capability of encouraging humans to create culture.

Cohen (1971: 41-44) verbalizes that adaptation transforms into a technology as well as a social process. As a technology, adaptation signifies that humans adapt their technology to face nature. Conversely, as a social process, adaptation means that when people face challenges, they try to improve their social institutions or structures.

Soemarwoto (2001: 48) also argued about the closeness of the approach between human adaptations to the environment. Soemarwanto voiced that changes in the environment taking place both rapidly and slowly trigger people to try to adapt themselves to the changes so as to produce traits or behaviors in accordance with their environment. Adaptation occurs when the environment (habitat) changes. Directly or indirectly these changes can have impacts on the inhabitants of the environment, both humans and animals.

In the analysing the society as a system, social system theory known as structural functional theory is applied. The structural-functional approach, as developed by Parsons that the approach can be seen from a number of basic assumptions being put forward, comprises: (1) society must be seen as a system with parts that are interconnected with one another, (2) even if dysfunction of tension and irregularities always occur, in the long term the situation can eventually be resolved through adjustments and institutionalisation processes, (3) changes in the social system will occur gradually or evolution will not take place in a revolutionary manner, (4) changes take place through three kinds of possibilities, such as as adjustment to change that come from external sources, changes occurring through differentiation of functional structures, as well as novel discoveries by society, and (5) the most important factor that has an integrating power is the consensus among members of society regarding certain societal values (Nasikun, 1991). Structural-functional approach emphasizes the order and changes (dynamics) in society. In this theory, according to Ritser (1992), society is described as a system made up of elements that are interrelated in balance. Changes transpiring in one part bring changes to other parts. To reveal how the people of Nusa Penida make interaction with the tourism industry, an analysis was carried out using the approach of Sociology of Tourism (Pitana, 2005).

\section{Results and Discussion}

\subsection{Pattern of Community Socio-Cultural Life during the Traditional Agriculture Period}

The pattern of socio-cultural life of the community of Nusa Penida during the traditional agricultural period (1980-1990) manifested in a time when seaweed cultivation was not introduced until the time it was cultivated extensively and intensively among the community. To reveal the life patterns of the people of the village of Nusa Penida in advance of the development of seaweed cultivation, an ethnographic framework approach was used (Koentjaraningrat, 1998), which concerned several cultural elements, such as livelihood system, system of knowledge and technology, custom, and religion.

Agricultural culture. As is the case with Balinese people, the majority of villagers in Nusa Penida work in the sector of agriculture, especially those who live in the hilly areas. Besides, raising poultry is just the leusire pursuit. The farming system in dry or rainfed land (dry land) is still conventional. Large, flat agricultural land is processed using tengala or plough of agriculture which is pulled by two female cows (by the local community is called 
logeng); meanwhile, for narrow land in the form of terraces, farmers work the land not with the plough, but with hoes. The types of plants that are suitable for cultivation by the community for the dry land type are palawija, the term for the crops beside rice, and nuts. The planting process is sufficient only to be done by the farmers themselves. The mobilization of additional personnel is required unless the busy period forces farmers to use additional labor (by the local people is called ngajak), namely by means of a mutual assistance system (mutual cooperation). Those who provide manpower assistance during the production process will be rewarded in the form of harvest (in kind).

Maritime culture. Villagers living on the coastal area are engaged in fishing and sea transportation business (or by local residents it is called ngaba jukung = jukung driver). There are two types of traditional knowledge systems related to fishing (maritime culture), such as traditional fisherman knowledge and sea transportation business-related knowledge. These two kinds of knowledge have been entrenched among coastal communities.

In a society and culture that has not been influenced by modern science, in essence there is a system of knowledge. Every culture is certainly made up with the complexity of knowledge about the nature of plants, animals, objects, and knowledge of fellow humans who live around it. This form of knowledge is obtained from the results of observations and experiences abstracted by the human mind into concepts, theories, and convictions (Koentjaraningrat, 1998: 213314). The knowledge possessed by each culture varies, depending on the natural environment in which humans live. As is the case with communities in the coastal areas of Nusa Penida, residents living in such areas have basic knowledge of the natural surroundings, especially those related to marine knowledge. This knowledge system is used to meet practical needs in the shipping sector, both in fishing and for sea transportation. As a coastal community, their lives depend on marine products. They know the state or situation of the sea at all times and have learned which time is exact for them to go out to sea or do activities at sea. For fishing purposes (which the local people call "melas), fishermen can go to sea every day. Nevertheles, the days that are good or profitable are six to eight days before tilem (full moon period), or it can also start from the eighth day (manda pang kutus which is called manda wayah) to six days after the tilem. These effective days are made for catching grouper (kokak fish) for twelve to fourteen days, while the remaining days are used for catching mackerel.

As fishermen whose daily work is fishing, people living in the coastal areas of Nus Penida have certain ways of knowing that in a certain place there is a shoal of fish. The trick is to take the trial and error system over and over again. According to the confessions of several local fishermen, the existence of fish is often found in places where the currents of the water are turning (meeting currents). Big waves usually occur from January to mid-February (sasih kawulu). In these months the wind blows hard. Likewise, from mid-April to early June (Sasih Jiyestha, Sadha), the waves will become tides. The situation in these months serves a challenge for fishermen to go fishing. The impact of the tidal waves also causes the fish to rarely eat the bait (keweh ngamahin), so that the catch of the fish decreases in number. Apart from the time of Sasih Kawulu, Jiyestha, and Sadha, fishermen can catch fish safely in places that are often traveled.

In addition to skills of fishing, coastal communities also have deeper knowledge about marine in relation to the interests of sea transportation businesses. The brigega (skipper) of jukung generally has adequate knowledge about the proper jukung equipment or materiel for sailing, the load capacity of the jukung, the way of recognising and control sea conditions, including the movement of currents. The movement of has a great impact on the safety in sailing and the speed of the boat to its destination. According to instructions from several 
bagenda, there are several terms developed in connection with the state of sea water, namely what is called luah and aus. Luah represents the condition when the currents move east. The movement of the current is driven by the blowing wind from the west. Such condition serves an exact moment to sail from the west, such as the departure of a boat from Sanur Beach to Nusa Penida. The condition of the current movement taking place in the opposite direction, towards the west, is called wear. It constitutes a fruitful moment for the departure of the jukung to Sanur Beach. The sea water condition is also influenced by weather conditions which then affect the conditions of the wave. Anticipation of this situation is carried out by departing / sailing earlier, because the weather is quite calm in the morning and the trip is closed until noon, around 14.00 (Western Indonesian Time). Now, traditional transportation (jukung 'boats') is no longer available since it has been replaced by fast boats.

Customs System. Universally, almost all human beings divide their life cycle into stages throughout a person's life; starting from the period of infancy to the period of weaning, childhood, adolescence, puberty, the period after marriage, pregnancy, and so on (Koentjaraningrat, 1998: 91). In general, for Balinese people, during the transition from one growth phase to the next, a special ceremony is usually held with a small party as an expression of matur suksma (gratitude). The holding of ceremonies throughout the life cycle is a result of the awareness that every time entering a new stage in the life cycle makes a person enter into a new and wider social environment. There is a view that the period of transition from one phase of life or social environment to the next phase of life or social environment is a period full of dangers, both real and occult. Therefore, life cycle ceremonies often contain elements to repel magical dangers (Koentjaraningrat, 1998: 92).

In ancient times before the development of seaweed cultivation, most of the life of the people of Nusa Penida depended on upland agricultural production, despite the uncertainty of their results. Such a condition seems to have affected the aspects of human life and culture. Likewise with the holding of life the cycle ceremony throughout an individual's life. The most unique and typical tradition of the people of the village of Nusa Penida is mekandang. The procedures for the implementation of the ceremony is much different from that of Balinese people in general. The results of interviews with traditional elders in one of the hill villages, Dusun Adegan Desa Ped, revealed that mekandang ceremony could be held when a baby is more than one month and seven days old or at any time; there is no bound to time but it depends on the capability of the family concerned since it is classified as a big event for the local village community. It is because the mekandang ceremony is made up of a series of several ceremonial activities held simultaneously. The procession of the ceremony begins with the ceremony of mesambutan (cutting of hair), then ends with the mekandang, which includes the activity of rare metekep guungan siap (babies are put in a cage for chickens). This whole series of ceremonies is called mekandang.

Religious System. One of important and must-have devices for humans in living their lives is divine belief or faith. By some people this aspect is considered incarnate as religion. Religion aims to achieve spiritual peace and physical well-being. The human need for the importance of security is the central starting point for humans to have faith in God and the need for religious life.

As a group of people embracing Hindu religion, most of the people of Nusa Penida have a system of belief called pancasradha. The phrase consists of two words, panca which means five and sradha which means belief. So, pancasradha refers to five beliefs in Hinduism, namely: 1) Widhi Sradha, belief in the existence of Hyang Widhi (God Almighty) as the exciting creator of all nature and things therein, preserves the results of creation, and dissolves everything that is created and returns it to its origin, 2 ) Atma Sradha, belief in the existence of 
atma in every creature, 3) Karmaphala Sradhai, belief in the law of action (law of karma) or also called the law of cause and effect (causality). Everything that is in the form of action (karma) brings about a result in the form of karmaphala (result of action), 4) Punarbhawa Sradha, belief in reincarnation or rebirth after death. Atma that is still bound to worldly influences is drawn by the world to be reborn. Reincarnation ends when atma is free from the bonds of worldly influence and atma reunites to its origin, namely Paramaatma / Hyang Widhi, and 5) Moksa Sradha, belief in the existence of moksa, namely sukha tan pawali dukha (eternal happiness). The integration of atma with Hyang Widhi is called moksa (Perbasana, 2018).

As is the case with the Hindu community in Bali, the people of Nusa Penida preserve the environment, especially in trees that are annual (tanem tuuh) in age, such as coconut trees, mango trees, jackfruit trees, teak trees, all of which are expressed in the form of the implementation of the ceremony of Tumpek Bubuh/Uduh or Tumpek Pengatag which takes place on Saniscara Kliwon Wariga. On that day a worship ceremony was carried out for Sanghyang Widhi in his manifestation as Dewa Sangkara (the god of plants). In terms of the purpose, the ceremony is carried out as an expression of gratitude for the gift of Ida Hyang Widhi in creating nature and plants.

In addition, supernatural power or spirit on land is believed to exist, such as believing in wong samar (giddy people), memedi, and tonya. These spirits generally live on the edge of ravines or in valleys, hilly shrubs and beaches, and under large trees such as banyan and kepuh. The coastal communities of Nusa Penida also recognize the belief that the god resting or ruling in the sea is Dewa Baruna or well known as Bathara Segara. The god manifests in the form of a large fish statue (Ulam Agung) which is adored by the local community at Pura Segara Penataran Ped.

\subsection{Pattern of Community Socio-Cultural Life of Nusa Penida during the Seaweed Cultivation Period (1990-2010)}

In the period 1990 - 2010, seaweed cultivation had developed rapidly in Nusa Penida. During the period the seaweed had begun to be maintained and processed intensively and widely among the community; not only occupied by inhabitants who live in coastal villages but also by those who live far away, in hilly areas.

Farmers' Traditional Knowledge of Seaweed. Apart from the traditional knowledge system with regard to the purposes of fishing, traditional knowledge in other marine sectors among the coastal communities of Nusa Penida is farming-related knowledge. This kind of knowledge is no less important as one of the factors supporting the success of farmers in cultivating seaweed (Suwendri, 2005: 69-70). From the results of interviews conducted with the informants, who were previously farmers cultivating the seaweed on August 12, 2020, it is discovered that according to the informant's experience, at the time of planting and picking seaweed, a set of traditional knowledge related to the ebb and flow of sea water is required. The condition of the sea water can be predicted from the presence of the moon, both during the full moon and during the dark sky (tilem). Counting the days during the phase of tilem or after full moon is by the local community called manda, for example manda apisan, manda pang pindo, manda pang telu, manda pang pat, manda pang lima, manda pang enem, manda pang pitu, manda pang kutus, manda pang sia, manda pang dasa, manda pang solas, manda pang roras, manda pang telulas, dan manda pang patbelas. Among these days, only 10 days are productive days for cultivating seaweed that are five days in advance of the tilem or during the phase of full moon period and five days afterwards. This means that the process begins at the stage of planting and picking the seaweed that is starting from the period of Manda Pang Dasa and ending in 
period of Manda Pang Lima. During the period of manda-manda, the condition of the sea water receded, while on days other than that the period, the sea water will have started to tide, the height reached approximately one meter and is called by the local community as kunda (small tide). At the present time the sea water height is neither too high nor too low. The condition usually lasts from early morning to period of morning and especially on the sixth to the tenth day (manda pang enem kanti manda pang dasa).

Other knowledge the seaweed-cultivating farmers also need to have is the one that is associated with maintenance or supervision activities. There are certain months according to the calculation of the Saka year, the so-called sasih-sasih, which have an impact on the growth of seaweed, like Sasih Kawulu which takes place from February to early March and Sasih Jiyestha and Sadha which takes place from mid-April to early June. During these months, strong winds and tidal waves (yeh jelek) take place, especially during the day, starting from the second day to the fourth subsequent to the full moon period. Amidst the season, the seaweed is attacked by pests including yellow wire rods, bulung selem, and debris carried by the waves which then stick to the planted seaweed.

Seaweed Farming. Aside from mastering the traditional knowledge system in the marine sector, seaweed farmers genuinely need to master the appropriate cultivation techniques in order that the productivity and the quality can be made optimal.

In the process of cultivating seaweed, there are several methods that can be applied (Aslan, 1999: 54-64). Seaweed cultivated by the coastal communities of Nusa Penida is processed by off-bottom method, and not by floating and bottom methods. The off-bottom method is applied considering that the bottom of the Nusa Penida coastal waters is made up of sand, making it easier for the installation of stakes. In interviews conducted with informants, who were previously seaweed farmers in Desa Ped on August 12, 2020, it was found that the farmers' experiences in farming seaweed, several flows of activity are taken, including: determining / selecting location, planting, maintenance or weeding, and ending up with harvesting. At post-harvest, the farmers sort the seaweed to provide seeds and then dry the rest (Suwendri, 2005: 98).

Furthermore, in the context of seaweed cultivation activities in the Nusa Penida area, farmers are grouped into a number of social institutions in the form of organizations or associations, which are called Kelompok Petani Rumput Laut (the Seaweed Farmers Group). The group was first formed in 1986 in Desa Jungutbatu, and then was followed by other villages in Nusa Penida (Nusa Gede). Until the last year, namely 2001, the formation of Seaweed Farmers Group numbered 58 with a total of 2,277 farmers (Dinas Perikanan Kecamatan Nusa Penida, 2003). The group was formed on the basis of the awareness of the seaweed farmers themselves. The formation of the group aims to improve the welfare of the inhabitants.

Additionally, seaweed cultivation in the Nusa Penida area is mostly done by women, while men are still working on dry land. If a family does not own arable land, both women and men will be involved together in an intensive seaweed cultivation process.

\subsection{Pattern of Community Socio-Cultural Life of Nusa Penida during Tourism Period (2014-2019)}

Tourism paradigm has actually emerged since the Dutch colonial government called Baliseering. The program emerged as one of the ethical political policy practices implemented in Bali (Resident van Bali en Lombok) in the 1930s. In the discourse of Baliseering the Dutch colonial government made Bali Island a Living Museum by exploring its exotic culture as a tourism commodity (Sendra, 2016: 97). In the following development Bali tourism came to a 
standstill. However, subsequent to the war for independence (physical revolution) it rose again, that is, in the 1950s (Vickers, 2013: 7). After mainland Bali had long triumphed in the world of tourism, then in 2014 the golden egg broke. Nusa Penida (Nusa Gede) began to expand in the tourism sector.

In the 2014-2019 period, tourism in Nusa Penida developed rapidly. The idea of making the island a tourist destination had actually been around for a long time. It can be seen from the existence of tourism activities in Nusa Lembongan and Jungutbatu. Tourism activities on the island of Nusa Penida (Nusa Gede) has just, nevertheless, been officially realised in 2014 with the holding of the first Nusa Penida Festival. The festival was held by the Culture and Tourism Office of Klungkung Regency for five days, from 2 to 6 June 2014. The event was centered in the village of Batunggul, Sub-district of Nusa Penida, the Regency of Klungkung (travel.kompas.com). The festival was enlivened with various activities such as traditional and cultural activities, introduction to natural tourism objects, marine tourism, and spiritual tourism. With the holding of the first festival, a sign of starting the Nusa Penida tourism is represented.

Transportation Service Provider. In essence, a tourism destination necessarily needs to provide the various needs needed by tourists so that the objectives of tourist visits can be satisfied. Jackson in Pitana (2005: 101) states that there are four main elements to achieve general and specific goals of tourists, that is to say facilities, accommodation, transportation, and attractiveness. Furthermore, Smith in Pitana (2005: 101) classifies the various needs for goods and services that must be provided by a tourism destination into six major groups, namely: 1) transportation 2) travel service, 3) accommodation, 4) food service, 5) activities and attractions / recreation / culture / entertainment, 6) retail goods, and 7) attractions (objects and attractions).

Provision of supporting facilities for tourism activities, such as road infrastructure and transportation services, both sea (crossings) and land transportation, is absolutely necessary. From the results of field survey conducted by researchers on August 1, 2020, the tourismsupporting facilities provided by the Bali Government together with the Klungkung Regency Government regarding infrastructure in the form of roads in Nusa Penida are in better condition than before. Condition of road access to natural tourism objects in hilly areas is also better but needs to be equipped with road markings in order to provide convenience and comfort for tourists who want to visit. Such a condition is certainly supported by the presence of the Roro Nusa Jaya Abadi boat dock crossing facility which was inaugurated and operated by the sixth President of the Republic of Indonesia Susilo Bambang Yudoyono on April 28, 2007 which provides crossing access from Nusa Penida to mainland Bali to the Padangbay pier.

Other sea transportation services, such as fast boats, are mostly managed by local communities either individually or in groups (communities). Established on the results of a field survey on August 2, 2020, there are four options for crossing places to Nusa Penida available, namely: 1) Sanur Beach Harbor; this port is the most popular port. In this port, there are many choices of fast boats. 2) Serangan Harbor, one of the ferry ports located in the tourist attraction area in the southern part of Bali. The port is close to the location of Benoa Harbor. Several fast boat operators at the Harbor of Serangan provide ferry services to Nusa Penida. 3) Padangbay Boat Harbor, Regency of Karangasem. At the port, in addition to the available fast boats, ferry services to Nusa Penida are also provided by using a Ferry (Roro Nusa Jaya Abadi) with a travel time of 45-60 minutes and the ship docked at the port of Mentigi, Nusa Penida. In addition, there are local people who choose to depart from Padangbay port if they want to bring their own vehicle. 4) Tribuana Harbor, Banjar Bias, Kusamba Village, Regency of 
Klungkung also provides fast boat crossing services to Nusa Penida. The availability of land transportation services in Nusa Penida is very easy to find because just as visitors arrive at the port of Nusa Penida, there are a number of private vehicle service providers. Alternatively tourists can choose to rent a motorbike or car complete with a driver or drive them alone.

Accommodation Service Provider. Nusa Penida tourism actors always strive to create comfort for tourists visiting the tourism destinations in their area; the stay period of tourists can be longer. One of them concerns the provision of accommodation services. The existence of accommodation in Nusa Penida is like a fungus in the rainy season. Therefore, getting accommodation in the area is not difficult. Tourists are free to choose which accommodation to take according to their needs and budget (based on the results of interviews with tourism actors in Nusa Penida on August 10, 2020). One of the unique inns is the Rumah Pohon, which measures 4x4 meters and is located in Kutampi Kaler village and there is also a tree house concept called the Nyuh Bengkok Tree House inn in Banjar Sental Kangin, Ped Nusa the village of Penida. From this place, tourists can enjoy the charming beauty of the surroundings, from cliffs, white sand beaches to the sunrise.

Objects and Attractions. Attractions serve a very vital component because they are the main causative factor for why tourists visit a tourism destination (Pitana, 2005: 102). Nusa Penida is rich in exclusively interesting and unique tourist objects such as spiritual, marine, and natural tourism objects for adventure.

In addition to the attractions mentioned above, there are also attractions that are packaged in the form of events, namely the Nusa Penida Festival which is an annual event held by Klungkung Regency (m.liputan6.com/global/read/433). Since the inauguration of Nusa Penida as a tourism destination in 2014 until early 2019 the Nusa Penida Festival has been held six times. In principle, all events share the common goal, namely as a means of promoting tourism objects, and that is why Nusa Penida is increasingly known among domestic and foreign tourists.
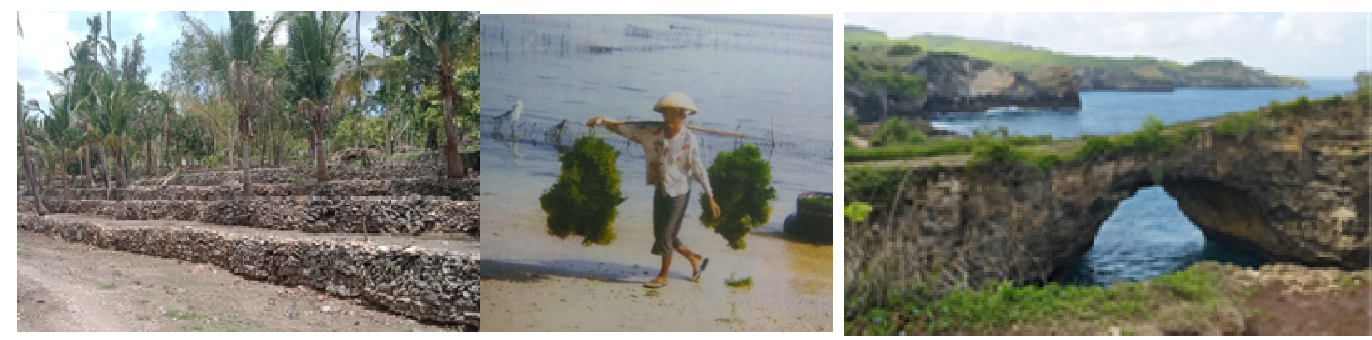

Figure. 1. Agricultural terrace (left), Seaweed farmer transporting their crops (center), Broken Beach is one of the preferred tourist attractions in Nusa Penida (right)

\section{Conclusion}

The pattern of socio-cultural life of the community of Nusa Penida has its own characteristics that share different attributes from one period to the next. The socio-cultural life during the seaweed cultivation and tourism in Nusa Penida shows a unique characteristic. The community of Nusa Penida do not completely abandon the agricultural sector, because 
seaweed cultivation has long been a mainstay of livelihoods for the population, and until now it is still an alternative field of job outside the tourism sector.

The community needs to participate in monitoring the rate of tourism growth with the aim that in subsequent developments it does not bring about damages to agricultural lands. The role of the government is also fundamentally required in zoning to avoid overlap between sectors. Another role of the government is to provide business capital stimulus to farmers to make them able to survive, facilitate post-harvest farmers so that prices remain stable, and establish the centres for the seaweed farmer as an option to support tourism (educational tourism). Today seaweed farmers are experiencing a dilemma of choice, between remaining as a seaweed farmer and switching to work in the tourism sector.

\section{References}

[1] Ariasa, Agus. dkk.: Pemetaan Potensi Objek Wisata dengan Sistem Informasi Geografis di Kecamatan Nusa Penida Kabupaten Klungkung dalam Jurnal Pendidikan Geografi Undiksha, Vol. 6, No. 2 (2018)

[2] Aslant, Laode M.: Budidaya Rumput Laut. Yogyakarta: Kanisius (1998)

[3] Astika, Ketut Sudhana, dkk.: Studi Pengembangan Potensi Kecamatan Nusa Penida Kabupaten Klungkung. Aspek Sosial Budaya. Bappeda Kabupaten Klungkung (1998)

[4] Buda: Marikultur dalam Kaitannya dengan Kegiatan pembangunan Wilayah Pesisir Utara Pulau Nusa Penida Kabupaten Klungkun Provinsi Bali (Suatu Kajian Budaya) (2005)

[5] Cohen, Y.A.: Culture as Adaptation, Man in adaptation the Cultural Present. Chicago: Adine Publishing Company (1971)

[6] Damayanti, dkk.: Strategi Pengembangan Pulau Nusa Penida sebagai Pariwisata yang Berkelanjutan, dalam Jurnal SOSHUM, Vol 5, No 2, (2015)

[7] Darsana. dkk.: Model Pengelolaan Pariwisata Bahari yang Berkelanjutan di Pulau Nusa Penida, dalam Jurnal Analisis Pariwisata, Vol.17, No. 1 (2017)

[8] Giddens, Anthony: Sociology. Oxford: Polity Press (1991)

[9] Kaplan, David dan Manners, Albert A.: Teori Budaya, Terj. Landung Simatupang. Yogyakarta: Pustaka Pelajar (1999)

[10] Kistanto, H. Nurdien: Transformasi Sosial Budaya Masyarakat Indonesia, dalam Jurnal Sabda, Vol. 13, No. 2 (2018)

[11] Koentjaraningrat: Beberapa Pokok Antropologi Sosial. Jakarta: Dian Rakyat (1998)

[12] Moleong, Lexy, J.: Metodelogi Penelitian Kualitatif. Bandung: Remaja Rosdakarya Offset (1999)

[13] Maliki, Zainuddin: Narasi Agung: Tiga Teori Sosial Hegemonik. Surabaya: LPAM (2004)

[14] Nasikun: Sistem Sosial Indonesia. Jakarta: Rajawali. (1995)

[15]Perbasana: Pancasradha: Sebagai Dasar Kepercayaan yang Universal. Denpasar: Widya Dharma (2018)

[16] Pitana, I Gde dan Gayatri, Pt. G.: Sosiologi Pariwisata. Andi: Yogyakarta. (2005)

[17] Poerwanto: Kebudayaan dan Lingkungan dalam Perspektif Antropologi. Yogyakarta: Pustaka Pelajar (2000) 
[18] Ritzer, George: Sosiologi Ilmu Pengetahuan Berparadigma Ganda. Jakarta: Rajawali Press (1992)

[19] Sanderson: Makro Sosiologi. Jakarta: PT Raja Grafindo Persada (2000)

[20] Santika, Budi. dkk.: Dampak Perkembangan Pariwisata Terhadap Kondisi Sosial Ekonomi masyarakat di Pulau Nusa Lembongan dalam Jurnal Destinasi Pariwisata, Vol.6, No1 (2018)

[21] Sayogyo, Pudjiwati: Kata Pengantar. Dalam Boserup, Ester. Peranan Wanita dalam Perkembangan Ekonomi. Terj. Mien Juobhaar dan Sunarto. Jakarta: Yayasan Obor Indonesia. p. xi - xv. (1984) 